Pergeseran Paradigma Pesantren, Oleh: Zaenal Arifin

\title{
PERGESERAN PARADIGMA PESANTREN
}

\author{
Zaenal Arifin*
}

\begin{abstract}
Abstrak
Pesantren adalah lembaga pendidikan Islam tradisional di Indonesia yang berperan penting dalam melestarikan dan mengembangkan ilmu-ilmu keislaman. Selain itu, pesantren berperan dalam pembentukan karakteristik umat Islam Indonesia. Pesantren dianggap sebagai semacam local genius karena keunggulannya dalam transmisi keilmuan maupun pelestarian tradisi.

Selama Orde Baru, pesantren bersaing dengan sekolahsekolah yang diakui oleh pemerintah. Selain itu, pola kehidupan manusia modern juga turut serta mempengaruhi eksistensi pesantren sebagai lembaga pendidikan Islam tradisional. Untuk mempertahankan eksistensinya, pesantren melakukan beberapa perubahan yang dianggap perlu, namun tetap menjaga tradisi-tradisi warisan masa lalu. Perubahan-perubahan yang dilakukan pesantren mencakup kurikulum, sistem pendidikan, dan orientasi pendidikannya.
\end{abstract}

Kata Kunci, Paradigma, Pesantren

\section{Pendahuluan}

Lembaga pendidikan formal dan pesantren adalah dua lembaga yang mempunyai banyak perbedaan. Sekolah atau lembaga pendidikan formal identik dengan kemodernan, sedangkan pesantren identik dengan ketradisionalan. Sekolah lebih menekankan pendekatan yang bersifat liberal, sedangkan pesantren lebih pada sikap konserfatif yang bersandar dan berpusat pada figur kiai $^{1}$ Namun, persepsi dikotomik semacam ini

\footnotetext{
* Dosen Mahad Aly Lirboyo Kediri

${ }^{1}$ Mudjia Rahardjo, Ed. Quo Vadis Pendidikan Islam: Membaca Realitas Pendidikan Islam, Sosial dan Keagamaan. (Malang: UIN-Malang Press, 2006), h. xxi.
}

Vol. 22 Nomor. 1 Januari 2011 
Pergeseran Paradigma Pesantren, Oleh: Zaenal Arifin

mungkin kurang begitu tepat, karena dalam kenyataannya, banyak pula pesantren yang telah melakukan perubahan baik secara struktural maupun kultural. Pesantren sebagai institusi sosial tidak hanya berbentuk lembaga dengan unsur-unsur pendukungnya, tetapi pesantren merupakan entitas budaya yang mempunyai implikasi terhadap kehidupan sosial yang melingkupinya. Sejak awal kelahirannya, pesantren berkembang dan tersebar di berbagai pedesaan. Pesantren sebagai lembaga pendidikan Islam yang khas Indonesia memiliki nilainilai strategis dalam pengembangan masyarakat Indonesia. Ia memiliki pengaruh kuat pada kehidupan masyarakat muslim.

Dalam sejarah pertumbuhan dan perkembangan pendidikan nasional di Insdonesia, pesantren telah menjadi semacam local genius. Di kalangan umat Islam di Indonesia, pesantren dianggap sebagai model institusi pendidikan yang mempunyai keunggulan, baik pada sisi tradisi keilmuan maupun pada sisi transmisi dan internalisasi nila-nilai Islam. Pesantren juga dinilai lebih dekat dan mengetahui seluk-beluk masyarakat yang berada di lapisan bawah. ${ }^{2}$ Dari sini, perlu digarisbawahi bahwa pesantren telah menjadi bagian yang tak terpisahkan dari proses pembentukan identitas budaya bangsa Indonesia. Secara substansial, pesantren merupakan institusi pendidikan keagamaan yang tidak mungkin lepas dari masyarakat, khususnya masyarakat pedesaan. Lembaga ini tumbuh dan berkembang dari masyarakat dan untuk masyarakat dengan memosisikan dirinya sebagai bagian dari masyarakat dalam pengertian transformatif. Pendidikan pesantren pada dasarnya merupakan pendidikan yang sarat dengan nuansa transformasi sosial. ${ }^{3}$

Pengabdian pada masyarakat yang dilakukan pesantren merupakan perwujudan dari nilai-nilai yang dianut pesantren. Masyarakat pesantren memandang seluruh kehidupan ini sebagai ibadah. Kehidupan duniawi ditempatkan dalam rangkuman nilai-nilai ilahi sebagai sumber nilai tertinggi. Dari nilai pokok ini lahir dan berkembang nilai-nilai luhur lainnya, seperti nilai keikhlasan, kesederhanaan, kesabaran, kemandirian dan lain-lain.

\footnotetext{
${ }^{2}$ Ibid.

${ }^{3}$ Ibid.
}

Vol. 22 Nomor. 1 Januari 2011 
Pergeseran Paradigma Pesantren, Oleh: Zaenal Arifin

Perkembangan dan perubahan yang dilakukan pesantren sebagai akibat dari persentuhannya dengan tantangan zaman sehingga melahirkan berbagai persoalan persoalan penting. Di satu sisi, pesantren berperan sebagai penerjemah dan penyebar ajaran-ajaran Islam dalam masyarakat. Karena itu, pesantren berkepentingan menyeru masyarakat untuk melakukan amar makruf dan nahi munkar. Di sisi lain, untuk mempertahankan jati dirinya sebagai sebuah lembaga pendidikan Islam tradisional, pesantren melakukan penyaringan ketat dalam pergaulannya dengan dunia luar atau masyarakat, yang tidak jarang menawarkan nilai-nilai yang bertentangan dengan nilai-nilai yang telah digariskan pesantren. Pemilahan pada salah satu sisi berarti akan menghilangkan keutuhan misinya, terlebih lagi bila meninggalkan kedua sisi itu secara bersama.

\section{Sejarah Munculnya Pesantren}

Sebelum membahas kapan pertama kali pesantren didirikan di Indonesia, terlebih dahulu perlu melacak asal-mula Islam masuk di Indonesia. Para ahli sejarah saling berbeda pendapat. Sebagian memperkirakan masuknya Islam ke Indonesia dimulai sejak abad ketujuh, sebagian lain memperkirakan bahwa Islam telah mulai berkembang di Indonesia sekitar abad ke-11, dengan salah satu bukti yang paling kuat, yaitu ditemukannya batu nisan Fatimah binti Maimun bin Hibatullah yang wafat pada $475 \mathrm{H}$. atau $1082 \mathrm{M}$. di Leran Gresik Jawa Timur. ${ }^{4}$ Terlepas dari perbedaan ini, kontak yang lebih intens antara budaya Hindu-Budha dan Islam telah dimulai sekitar abad ke13. ${ }^{5}$ Jalur Islam semakin memperoleh bentuknya ketika Walisanga (sembilan wali) mulai melakukan penetrasi dan berinteraksi dengan kekuasaan, yaitu ketika terjadi pergantian kekuasaan dari Majapahit ke Kesultanan Demak Bintara yang dipimpin oleh Raden Fattah pada abad ke-15. Pada masa ini, nilai-nilai Islam berangsur-angsur menggantikan budaya Hindu. Pada saat itu Islamisasi masyarakat Jawa yang dilakukan

\footnotetext{
${ }^{4}$ Anason, "Sejarah Masuknya Islam di Jawa," dalam Darrari Amin (ed.), Islam dan Kebudayaan Jawa (Yogyakarta: Gadjah Mada Press, cet. II, 2002), h. 28.

5 Ibid.
}

Vol. 22 Nomor. 1 Januari 2011 
Pergeseran Paradigma Pesantren, Oleh: Zaenal Arifin

Walisanga berjalan lempang. Pengaruh Islam menyebar hampir ke seluruh pulau Jawa. ${ }^{6}$

Islam masuk di Indonesia bisa diterima dengan mudah dan menyebar dengan cepat. Prosesnya berlangsung dengan damai. Secara sosiologis, penyebaran agama atau ideologi akan mudah dicapai melalui kekuasan, sebab kekuasaan merupakan sarana strategis membangun dan membina umat. Sementara penyebaran Islam di jazirah Arab dilakukan melalui penaklukan, di Indonesia penyebaran Islam dilandasi dengan nilai-nilai toleransi dan nilai-nilai budaya. Hal ini karena Islam yang didatangkan dari India dan Persia oleh para Walisanga tidak bisa lepas dari ajaran-ajaran dasar tasawuf. ${ }^{7}$ Pendekatan tasawuf ini terasa sesuai dengan watak masyarakat Jawa yang kala itu masih menganut agama Hindu-Buddha. Walisanga melakukan suatu proses yang tak berujung dan bertahap. Mereka berhasil menciptakan satu tatanan masyarakat santri yang saling damai dan berdampingan. Beberapa anggota Walisanga menggunakan pesantren sebagai tempat menyebarkan dan mengajarkan Islam kepada masyarakat Jawa dengan pendekatan yang sesuai dengan pandangan hidup mereka. ${ }^{8}$

Abdurrahman Wahid berpendapat bahwa pesantren merupakan subkultur yang memiliki tiga elemen penting, yaitu, pertama, pola kepemimpinan pondok pesantren yang mandiri tidak terkooptasi oleh Negara, kedua, kitab-kitab rujukan umum yang selalu digunakan dari berbagai abad, dan ketiga, sistem nilai yang digunakan adalah bagian dari masyarakat luas. ${ }^{9}$ Kepemimpinan pondok pesantren dikatakan unik karena memakai sistem kepemiminan tradisional, relasi sosial Kyiai dan santri dibangun atas dasar kepercayaan dan penghormatan kepada seorang yang memiliki ilmu keagamaan yang tinggi, sebagaimana ajaran sufi. Hal itu sejatinya bukanlah penghormatan kepada manusianya, tetapi lebih kepada ketinggian ilmu yang diberikan Allah SWT kepada seorang Kyiai. Elemen kedua dari pondok pesantren adalah memelihara dan mentransfer literatur-literatur umum dari generasi kegenerasi dalam berbagai abad. Dalam pendidikan pondok

\footnotetext{
${ }^{6}$ Ibid.

${ }^{7}$ Faiqoh, Nyai Agen Perubahan di Pesantren (Jakarta: Kurcica, 2003), h. 151.

${ }^{8}$ Ibid.

${ }^{9}$ Ibid., h. 14
} 
Pergeseran Paradigma Pesantren, Oleh: Zaenal Arifin

pesantren, aturan dalam terks-teks klasik yang dikenal dengan kitab kuning dimaksudkan untuk membekali para santri dengan pemahaman warisan yurisprudensi masa lampau atau jalan kebenaran menuju kesadaran esoteris ihwal status penghambaan di hadapan Tuhan, ${ }^{10}$ dan dengan tugas-tugas masa depan dalam kehidupan masyarakat.

\section{Fungsi dan Peran Pesantren}

Pesantren secara ideal mempunyai dua fungsi, yaitu mobilitas sosial dan pelestarian nilai-nilai etik dan pengembangan tradisi intelektual. Fungsi pertama menempatkan pendidikan pesantren sebagai sarana dan instrumen untuk melakukan sosialisasi dan transformasi nilai agar umat mampu melakukan mobilisasi sosial berdasarkan pada nilai agama. Fungsi kedua lebih bersifat aktif dan progresif, di mana pesantren dipahami tidak saja sebagai upaya mempertahankan nilai dan melakukan mobilisasi sosial, lebih dari itu merupakan sarana pengembangan nilai dan ajaran. Ini menuntut terjadinya interdependensi, otonomi dan pembebasan dari setiap belenggu baik struktural maupun kultural karena pengembangan intelektual bisa terjadi jika manusianya independen dan tidak terikat baik secara fisik maupun mental. ${ }^{11}$

Pesantren, sebagai suatu subkultur, lahir dan berkembang seiring dengan derap langkah perubahan-perubahan dalam masyarakat global. Perubahan-perubahan yang terus bergulir itu, cepat atau lambat, pasti akan berpengaruh pada masyarakat pesantren sebagai bagian dari masyarakat dunia. Oleh karenanya, tidaklah berlebihan jika A. Sahal Mahfudz menyebutkan bahwa ada dua potensi besar yang dimilki pesantren, yakni potensi pengembangan masyarakat dan potensi pendidikan. ${ }^{12}$ Dalam kaitan ini, bila ditilik dari kehadirannya, menarik kiranya untuk disimak bahwa institusi pesantren ternyata memilki keunikan tersendiri bila dibandingkan dengan perannya dewasa ini. Dalam hubungannya dengan potensi di atas, kehadiran pesantren

\footnotetext{
${ }^{10}$ Wahid, Pondok Pesantren Masa Depan, h. 16

${ }^{11}$ Wahid, Pondok Pesantren Masa Depan.

${ }^{12}$ Marzuki Wahid, dkk, Ed. Pesantren Masa Depan: Wacana Pemberdayaan dan Transformasi Pesantren. (Bandung: Pustaka Hidayah, 1999), h. 201.
}

Vol. 22 Nomor. 1 Januari 2011 
Pergeseran Paradigma Pesantren, Oleh: Zaenal Arifin

disebut unik sekuarang-kurangnya karena ada dua alasan sebagai berikut.

Pertama, pesantren dilahirkan untuk memberikan respon terhadap situasi dan kondisi sosial suatu masyarakat yang tengah dihadapkan pada runtuhnya sendi-sendi moral, melalui transformasi nilai yang ditawarkannya (amar ma'ruf dan nahy munkar). Kehadirannya, dengan demikian bisa disebut sebagai agen perubahan sosial (agent of social change), yang selalu melakukan kerja-kerja pembebasan (liberation) pada masyarakatnya dari segala keburukan moral, penindasan politik, pemiskinan ilmu pengetahuan, dan bahkan dari pemiskinan ekonomi. Institusi pesantren, dengan begitu, mengesankan telah berhasil mentransformasikan masyarakat di sekitarnya dari keburukan menuju kesalihan, dan dari kefakiran menuju pada kemakmuran atau kesejahteraan. Oleh karenanya, kehadiran pesantren menjadi suatu keniscayaan sebagai bentuk institusi yang dilahirkan atas kehendak dan kebutuhan masyarakat. Dengan kesadarannya, pesantren dan masyarakat telah membentuk hubungan dengan harmonis, sehingga komunitas pesantren kemudian diakui menjadi bagian tak terpisahkan atau sub-kultur dari masyarakat pembentuknya. Pada tataran ini, pesantren telah berfungsi sebagi pelaku pengembangan masyarakat. ${ }^{13}$

Kedua, salah satu misi awal didirikannya pesantren adalah menyebarluaskan informasi ajaran tentang universalitas Islam ke seluruh pelosok Nusantara yang berwatak pluralis, baik dalam dimensi kepercayaan, budaya maupun kondisi sosial masyarakat. ${ }^{14}$ Melalui medium pendidikan yang dikembangkan para wali dalam bentuk pesantren, ajaran Islam lebih cepat membumi di Indonesia. Hal ini tampaknya menjadai fenomena tersendiri bagi keberadaan pesantren di Indonesia yang dapat menjelaskan elan vital perannya tatkala melahirkan kader-kadernya untuk dipersiapkan memasuki segala sistem kehidupan masa itu.

Dengan institusi pesantren yang dibangunnya, para wali berhasil menginternalisasikan nilai-nilai Islam dalam lingkungan masyarakat.

\footnotetext{
${ }^{13}$ Ibid.

${ }^{14}$ Ibid.
} 
Pergeseran Paradigma Pesantren, Oleh: Zaenal Arifin

Idealisasi bangunan masyarakat yang ditempuh adalah sebuah masyarakat Muslim yang inklusif, egaliter, patriotik, luwes dan bergairah terhadap upaya-upaya transformatif. Misi kedua ini lebih berorientasi pada peran pesantren sebagai sebuah institusi pendidikan Islam.

\section{Pergeseran Paradigma Pesantren}

Istilah paradigma muncul dari teori revolusi sains yang dikemukakan oleh filosof Thomas Kuhn. Dalam menjelaskan terjadinya revolusi sains, Thomas Kuhn menggunakan istilah paradigma sebagai sistem yang menggambarkan keyakinan dasar dalam upaya pemecahan teka-teki di dalam ilmu. ${ }^{15}$. Demikian halnya dengan pesantren, jika pada masa awal berdirinya pesantren masih mampu manjawab persoalanpersoalan yang muncul dalam sosiokultur masyarakat sekitar, namun pada masa selanjutnya persoalan-persoalan yang muncul dalam masyarakat semakin kompleks, dan paradigma yang digunakan pesantren sudah kurang mampu atau bahkan tidak sesuai dengan harapan, maka para tokoh dalam pesantren berusaha mencari solusi yang tepat untuk dapat menjawab persoalan tersebut. Sebagaimana hasil penelitian yang dilakukan oleh Clifford Geertz, pendidikan tradisional (dalam hal ini adalah pesantren) akan tetap eksis dan diikuti oleh banyak kalangan masyarakat selama pesantren tersebut mendirikan madrasah atau lembaga pendidikan lain yang mampu memberikan kepuasan secara religius bagi masyarakat sekitar sebagai fungsi pembangunan Indonesia. Di sinilah apa yang dinamakan pergeseran paradigma pesantren terjadi, yaitu, pergeseran dari paradigma lama ke paradigma baru yang dianggap lebih tepat dengan kondisi sosiokultural masyarakat.

Paradigma yang digunakan oleh pesantren pada awal berdirinya tentunya disesuaikan dengan kondisi masyarakat sekitar pada waktu itu. Jika pada awal berdirinya pesantren kondisi masyarakat sekitar adalah sangat kental dengan budaya dan ajaran Hindu-Buddha, maka paradigma yang dipakai oleh pesantren pun harus sesuai dan tidak bertentangan dengan budaya lokal (Hindu-Buddha). Sedangkan dalam

${ }^{15}$ Ibid.

Vol. 22 Nomor. 1 Januari 2011 
Pergeseran Paradigma Pesantren, Oleh: Zaenal Arifin

Islam ajaran yang sangat menghormati budaya ajaran lain adalah ajaran tasawuf, di mana dalam ajaran tasawuf rasa toleransi sangat dikedepankan.

Pada perkembangan selanjutnya, kondisi masyarakat sekitar pesantren telah memeluk agama Islam dan mewarnai budaya lokal dengan ajaran Islam, sebagaimana penyebaran Islam yang dilakukan oleh para Walisongo. Karena penanaman ajaran tasawuf atau tauhid telah berhasil dilakukan, maka kalangan pesantren menganggap sudah saatnya untuk mengubah orientasi dari ajaran tasawuf kepada penerapan hukum fikih. Selain itu, pergeseran tersebut juga dikarenakan banyaknya generasi pesantren yang belajar di negeri Arab untuk memperdalam ajaran Islam. Kondisi bangsa Arab saat itu terkenal dengan al-ahlul al-hadits dan ajaran Islam yang dikembangkan lebih kental dengan fikihnya.

\section{Paradigma Tasawuf}

Jika dilacak, sejarah tradisi keilmuan Islam di pesantren bersumber dari dua masa. Pertama, pengetahuan keislaman yang datang ke Nusantara pada abad ke-13. Kedua adalah ketika anak-anak muda menuntut ilmu di semenanjung Arabia, khususnya di Makkah dan sekembalinya ke tanah air mereka mendirikan pesantren-pesantren, kemudian menjadi pesantren-pesantren besar. ${ }^{16}$ Pada masa pertama, wujud keilmuan Islam yang datang ke Indonesia adalah dalam bentuk tasawuf.

Sementara itu, pada masa kedua muncul ilmu-ilmu keislaman yang lebih mendalam pada fan fikih, hal ini ditandai dengan lahirnya ulama-ulama fiqih besar seperti Nawawi Banten, Abdul Ghani Bima, Mahfudz Tremas, dan Khalil Bangkalan. ${ }^{17}$

Gelombang pertama keilmuan Islam yang bercorak tasawuf terjadi karena Islam masuk Indonesia dari Persia dan kemudian India. Kedua wilayah ini banyak memunculkan ulama-ulama tasawuf. ${ }^{18}$ Ilmu tasawuf adalah ilmu yang memungkinkan manusia mengetahui diri dan

${ }^{16}$ M. Dian Nafi' dkk. Praksis Pembelajaran Pesantren. (Yogyakarta: LKiS, 2007), 78

${ }^{17}$ Ibid.

${ }^{18}$ Ibid.

Vol. 22 Nomor. 1 Januari 2011 
Pergeseran Paradigma Pesantren, Oleh: Zaenal Arifin

kedudukannya di hadapan Allah Swt. Modus hubungan antara manusia dengan Sang Khalik menjadi kajian utama, seperti tawakkal, zuhud dan sebagainya. Modalitas manusia yang berupa jasad, akal, ruh dan nafsu serta qalbu sama pentingnya sebagai isi ilmu tasawuf, dengan perihal rute dan terminal perjalanan ruhani. Semua ini merupakan ilmu yang tidak cukup diceramahkan, melainkan hanya bisa dipahami dan dijalani.

Dalam tasawuf tingkatan pengetahuan atau ilmu dibagi ke dalam empat tingkatan, yaitu : syariat, tarekat, hakikat, dan makrifat. Syariat adalah ilmu yang dianggap sebagai kulit dari ajaran Islam. Ajaran Islam syariat ini lebih bersifat legal-formal. Dengan kata lain, ajaran ini memandang suatu persoalan sesuai dengan ketentuan hukum dan syariat yang berlaku, serta sesuai dengan madzhab fikih yang dianut. Tingkatan kedua, yaitu tarekat, sebagaimana arti istilah Arab Thariqat itu sendiri, yakni "jalan", jalan untuk mencari ketentraman dunia dan akhirat melalui bacaan-bacaan aurad (dzikir) yang sering dilakukan melaui istighatsah, manaqib, dan sebagainya.

Sementara aliran yang ketiga, yaitu hakikat (haqiqat) lebih pada makna dan substansi ajaran Islam, yaitu tauhid, dan ketika memandang persolan lebih bersifat toleran asalkan substansinya tidak melenceng dari tauhid. Akhlak dan perilaku dalam tingkatan yang ketiga ini lebih dikedepankan. Sedangkan tingkatan yang terakhir, yaitu makrifat ( $m a$ 'rifat), mengajarkan tauhid yang lebih mendalam lagi sampai pada kefanaan diri dan alam, yang ada hanyalah subtstansi Tuhan, manusia yang sudah berada pada tingkatan ini merasa telah bersatu dengan Tuhan (wahdatul wujud).

Jika kita melacak sejarah ilmu tasawuf, sebenarnya sudah ada semenjak periode tabiin, namun pada masa itu tasawuf tidak terpaku pada satu atau dua aliran tertentu. Namun, ketika memasuki periode pasca-Imam Al-Ghazali, ilmu taswuf mulai membentuk aliran-aliran, dan bersifat akhlaqiyah dan 'ubudiyah. Pada perkembangan selanjutnya ilmu tasawuf bercabang-cabang menjadi beberapa aliran, bersamaan dengan pembukuan ilmu-ilmu fiqih yang dipelopori oleh para imam madzhab.

Vol. 22 Nomor. 1 Januari 2011 
Pergeseran Paradigma Pesantren, Oleh: Zaenal Arifin

\section{Paradigma Fikih}

Sebagaimana karakter syari'ah yang sangat menunjukkan sifat legal formal, fiqih juga demikian, selalu mengedepanan sifat legalformal, doktriner, serta justifikasi yang berkecenderungan menampilkan Islam serba harfiah dan sesuai dengan hukum fiqih atau tata aturan syari'ah yang sah. Model berfikir serba formalistik atau legalistik tersebut berbeda kontras dengan corak Islam yang mengedepankan hakikat dan substansi sebagaimana logika ilmu kalam dan tasawuf. Bagi kalangan syariah atau fiqih, bahwa islam itu ialah isi dan kulit sekaligus, substansi itu penting, tetapi formalisasi justru akan mengamankan substansi. ${ }^{19}$

Karakter legalitas, doktriner dan justifikasi pada Islam syariat merupakan keniscayaan dari paradigma Islam syariat yang berorientasi serbahukum atau fikih Islam dalam logika al-Ahkam Al-Khamsah (lima prinsip hukum) yaitu, wajib, sunnah, haram, makruh dan mubah. Logika ini melahirkan kaca mata serbahitam-putih. ${ }^{20}$

Ilmu fikih sendiri mulai memperlihatkan perkembangannya sekitar abad ke-13 M., tepatnya pada masa pemerinyahan Bani Abbasiyah. Pada masa tersebut, keilmuan Islam sangat dipengaruhi oleh keilmuan Yunani kuno yang telah diterjemahkan ke dalam bahasa Arab. ${ }^{21}$

\section{Orientasi Tasawwuf}

Sebagian besar kitab kuning yang dipelajari di pesantren mengandung nuansa-nuansa tasawuf. Di antaranya, misalnya, adalah Durrah an-Nashihin, Bidayah al-Hidayah, Minhaj al Abidin, Ihya' 'Ulum ad-Din, Mizan al-Kubra, dan Syarh al-Hikam. Orientasi kitab kuning seperti ini sangat mempengaruhi pandangan, pemikiran, dan sikap hidup masyarakat pesantren. Di satu sisi, orientasi itu dapat membentuk kepribadian yang luhur. Di sisi lain, pemahaman atas sufisme dan kehidupan tarekat seringkali mengalahkan dimensi nalar. Keadaan ini terbukti ketika mantiq kurang memperoleh perhatian. Kitab

${ }^{19}$ Haedar Nasir. Gerakan Islam Syari'at (Jakarta: PSAP, 2007), h. 426.

${ }^{20}$ Ibid., h. 428

${ }^{21}$ Siti Maryam, dkk. Sejarah Peradaban Islam; Dari Zaman klasik Hingga Modern, (Yogyakarta: Lesfi, 2004), h. 97. 
Pergeseran Paradigma Pesantren, Oleh: Zaenal Arifin

As-Sulam Al-Munauraq, kitab tentang logika memang masih diajarkan di beberapa pesantren. Akan tetapi, kitab ini tidak dijadikan kajian yang penting. Tampaknya imbauan Imam al-Ghazali untuk mengkaji ilmu ini tidak cukup mampu mengalahkan pernyataan Ibnu Shalah dan Imam Nawawi yang justru mengharamkannya.

Fenomena di atas sangat menarik karena kajian tentang tasawuf memperoleh aspirasi yang tinggi. Pada saat yang sama, kajian tentang logika terjadi sebaliknya. Namun kita bisa meihat terlebih dahulu tokoh yang meganjurkan untuk mempelajari logika dan tokoh yang mengharamkan mempelajari logika. Al-Ghazali adalah filosof Muslim yang juga sufi besar di abad pertengahan. Karangannya tentang tasawuf, di antaranya Ihya' 'Ulûm ad-Dîn dan Bidâyah al-Hidâyah banyak dipakai di pesantren, meskipun kadarnya sangat minim. Melihat latar belakang Imam al-Ghazali, sangat dimaklumi jika beliau menganjurkan untuk mempelajari ilmu logika dan filsafat. Sebaliknya, Ibnu Shalah dan Imam Nawawi mengharamkan mempelajari logika dan filsafat. Keduanya adalah ahl al- $\underline{h} a d i t s$.

Dalam ilmu tasawuf, diajarkan penyerahan diri kepada sang khalik secara muthlak. Artinya, setiap yang dikerjakan merupakan untuk beribadah kepada Tuhan. Sebagaimana yang disebutkan dalam Al-Quran, tujuan jin dan manusia diciptakan tidak lain hanyalah untuk beribadah kepada sang Allah. Bentuk ibadahnya pun bermacam-macam, setiap perbuatan yang bernilai baik adalah ibadah, tidak terpaku pada hukum syariat. Nilai baik dalam ibadah tersebut juga tidak secara baku ditetapkan, namun mempunyai neraca-neraca kebenaran yang universal.

Perlu ditekankan bahwa yang paradigma tasawuf di sini tidak dimaknai secara sempit, yakni ajaran tarekat yang justru malah bersifat individualis dan seringkali menimbulkan rasa pesimistis. Namun tasawuf secara luas yang menekankan pada rasa toleransi dan kesederhanaan yang menimbang kebenaran secara universal.

\section{Orientasi Fiqih}

Hukum fikih yang ditafsirkan secara tekstual selalu menghadirkan produk hukum positif yang terkesan fikih sentris dalam beragama. Hal ini dapat kita lihat dari, misalnya, metode bahtsul masâ'il. Kajian ini selalu mengedepankan 'ibarah hanya dari kitab-

Vol. 22 Nomor. 1 Januari 2011 
Pergeseran Paradigma Pesantren, Oleh: Zaenal Arifin

kitab fikih muktabar. Sedangkan kitab-kitab ajaran tasawuf tidak dijadikan acuan dalam mengambil keputusan hukum. Untuk melihat orientasi fikih di pesantren, kita juga harus melihat kadar materi pelajaran yang diajarkan. Ketika pesantren sudah mengadopsi sistem pembelajaran modern yang berparadigma positivistik, kitab-kitab yang diajarkan pesantren kadar fikihnya lebih tinggi dibandingkan dengan kadar kitab yang berorientasi tasawuf. Setiap masalah dipandang melalui hukum fikih dan metode intepretasi yang tekstualis. Orientasi fikih selalu menundukkan realitas kepada kebenaran fikih yang berwatak hitam dan putih (halal-haram). Akibatnya, sesuatu yang berbeda dan berada di luar hukum fikih selalu dianggap sebagai barang bidah bahkan haram. Ironisnya pemahaman keagaman yang sempit ini justru banyak dianut umat Islam. Ini karena pemahaman tersebut selain mendapat dukungan dari kelompok yang dominan di masyarakat juga karena pelestariannya dilakukan dengan berbagai cara dengan memanfaatkan berbagai media. Dengan demikian ajaran agama yang seharusnya menjadi dasar perubahan, bahkan menjadi alat pelanggengan status quo.

Mayoritas pesantren masa kini terkesan berada di menara gading, elitis, jauh dari realitas sosial. Problem sosialisasi dan aktualisasi ini ditambah lagi dengan problem keilmuan, yaitu terjadi kesenjangan, alienasi dan diferensiasi antara keilmuan pesantren dengan realitas sosial. ${ }^{22} \mathrm{Hal}$ ini semakin menjauhkan pesantren dengan basis primordialnya, yaitu warga masyarakat. Akibatnya, muncul rasa rendahnya rasa memiliki masyarakat terhadap pesantren, dan sebaliknya, pesantren tidak lagi merasa menjadi bagian milik masyarakat.

\section{Pergeseran Orientasi Tasawuf ke Orientasi Fiqih}

Pada masa awal munculnya pesantren (juga masa awal penyebaran Islam di Indonesia), kondisi sosiokultur masyarakat masih diwarnai oleh ajaran Hindu-Buddha. Ajaran tasawuf dalam Islam yang lentur terhadap keragaman mempermudah diterimanya Islam oleh

${ }^{22}$ Jamaludin Malik, Ed. Pemberdayaan Pesantren (Yogyakarta: Pustaka Pesantren, 2005).

Vol. 22 Nomor. 1 Januari 2011 
Pergeseran Paradigma Pesantren, Oleh: Zaenal Arifin

masyarakat. Islam yang masuk ke Indonesia memang dibawa oleh orang yang dari Persia dan India yang kental dengan ajaran tasawuf. Ketika ajaran Islam sudah menyebar hampir seluruh masyarakat Indonesia, khususnya jawa, banyak tokoh Islam dari kalangan pesantren belajar dan memperdalam ajaran Islam ke negeri Arab. Hal ini mulai merubah orientasi penyebaran ajaran Islam dari yang semula hanya mewarnai budaya lokal dengan ajaran tauhid Islam menjadi penerapan hukum fikih dalam kehidupan sehari-hari. Hal ini karena budaya lokal, seperti larung, sesajen dan sebagainya dianggap sangat dekat dengan kesyirikan sehingga perlu dihilangkan.

Setelah mengalami pergesaran orientasi, kurikulum yang ada dalam pesantren pun mengalami pergeseran dan perubahan sesuai dengan orientasi dan paradigma yang dipakai. Dilihat dari segi kurikulumnya, pesantren terbagi menjadi tiga model atau tipe, yaitu :

1. Pesantren Salafiyah atau Tradisional, yaitu pesantren yang sistem pendidikannya semata-mata berdasarkan pada pola-pola lama atau klasik. Jadwal dan kitab yang dikaji tidak mempunyai aturan yang baku, dan sistem pengajarannya masih menggunakan sistem lama, seperti sorogan, bandongan wetonan dan sebagainya.

2. Pesantren semi modern, yaitu pesantren yang sudah mengadopsi kurikulum sekolah, manajeman dan kurikulum sudah tertata rapi, seperti pembagian kelas (klasikal). Ustadz yang mengajarnya pun dibagi sedemikian rupa, sistem pembelajarannya pun tidak jauh beda dengan sistem yang ada di sekolah formal. Pada pesantren ini, pengelolaan kependidikan sudah tidak dipegang secara penuh oleh Kyai, tetapi diambil alih oleh pengurus yang terkotak-kotak sesuai dengan bidang-bidang, meskipun kebijakan tertinggi masih dipegang oleh Kyiai.

3. Pesantren modern, yaitu pesantren yang kurikulumnya dan manajemen pembelajarannya mengadopsi kurikulum pemerintah/formal secara total. Materi pelajaran yang disampaikan oleh sekolah formal juga disampaikan oleh pesantren modern, Kyiai tidak lagi memegang otoritas penuh, namun hanya sebatas penasehat atau pimpinan yayasan yang juga tunduk pada aturan pemerintah.

Vol. 22 Nomor. 1 Januari 2011 
Pergeseran Paradigma Pesantren, Oleh: Zaenal Arifin

Perbedaan-perbedaan pesantren di atas menunjukkan adanya pergeseran-pergeseran pada sistem pendidikan dan kurikulum pesantren. Karena pada awal kemunculannya, pesantren hanya mempunyai sistem pendidikan tunggal, yaitu tradisional. Pergeseranpergeseran kurikulum tersebut sangat dipengaruhi oleh kebijakan pemerintah yang mewajibkan pendidikan formal selama sembilan tahun. Hal ini membuat pesantren mau tidak mau juga harus memberikan kelonggaran kepada santri untuk dapat merealisasikan hal tersebut. Selain itu, ketakutan-ketakutan rasional positivistik juga sangat mempengaruhi pergeseran kurikulum pesantren, di mana rasional positivistik selalu mengukur segala sesuatu dengan materi.

\section{Pergeseran Budaya Pesantren}

Budaya-budaya yang dulu dimiliki pesantren sebagai identitas serta sebagai pembentukan kepribadian, saat ini telah mengalami pergeseran yang sangat jauh. Hal ini dapat kita lihat dari pola hidup kaum santri saat ini. Pada masa dulu, banyak santri yang memenuhi nafkahnya dengan jalan mencari dengan tangan sendiri. Hal ini sudah jarang ditemukan di banyak pesantren mana pun, selain budaya masak sendiri juga sudah hilang digantikan budaya makan di warung atau kost. Budaya-budaya pesantren yang dulunya menawarkan kesederhanaan dan toleransi serta solidaritas, saat ini mulai bergeser pada budayabudaya modern yang identik dengan kemewahan, konsumtif, dan individualis. Hal ini terbukti dari pola kehidupan santri saat ini, di mana rasa solidaritas terhadap sesama santri sudah mulai mengendur.

Pesantren pada masa lampau selalu menggunakan nama-nama dari daerah di mana pesantren tersebut berdiri, seperti Pesantren Jampes, Pesantren Bendo, Pesantren Lirboyo dan sebagainya. Kini pesantren-pesantren yang muncul kemudian berubah nama menjadi menggunakan nama-nama berbahasa Arab, seperti Pesantren Salafiyah, Al-Ishlah, Al-Ma'ruf, Al-Amin dan sebagainya. Penggunaan bahasa Arab itu sendiri mulai menguak sejak abad ke-20. Hal ini menunjukkan bahwa pesantren mulai menjaga jarak dengan adat atau budaya setempat. Ini merupakan pilihan sikap untuk membatasi diri pada tugas langsung untuk melayani masyarakat sekitar. Hal ini tidak cukup dipandang sebagai mekanisme pesantren untuk menyatakan

Vol. 22 Nomor. 1 Januari 2011 
Pergeseran Paradigma Pesantren, Oleh: Zaenal Arifin

kehadirannya secara berbeda dan abai terhadap adat dan budaya sekitar. Sebaliknya, hal ini merupakan pertanda dimulainya era baru dalam pembelajaran dan budaya di pesantren. ${ }^{23}$

Pesantren yang selama ini merupakan benteng pertahanan masyarakat dari gerusan neoglobalisme dengan berbagai implikasinya, namun sekalipun demikian fakta bahwa perubahan sosial yang menjadi sangat cepat berlangsung di semua belahan dunia. Tidak dapat diabaikan, hal ini menjadi tantangan besar pesantren. Perubahan sosial sekarang ini bercirikan mondial, spektakuler, dan radikal. ${ }^{24}$ Mondial, karena perubahan itu mencakup seluruh pelosok negri di dunia; nyaris tidak ada bagian dari dunia yang bebas dari gelombang perubahan itu. Spektakuler, karena perubahan tersebut terjadi serentak, mendadak, dan tidak memberikan waktu yang cukup bagi bangsa-bangsa untuk mempersiapkannya. Radikal karena perubahan itu mempengaruhi kehidupan manusia sampai pada sendi-sendi yang mendasar, seperti akhlak dan pandangan hidup, celakanya lagi perubahan-perubahan tersebut berjalan searah, sehingga memungkinkan terjadinya pengerucutan budaya dunia menjadi kebudayaan tunggal.

\section{Penutup/Kesimpulan}

Budaya pesantren selama ini dicirikan oleh banyak hal, seperti figur kharismatik seorang kyai yang menjadi panutan, tolong-menolong, kesetiakawanan, suasana persaudaraan dan kebersamaan, hemat dan sederhana, serta sikap jujur dan berani menderita. Saat ini cirtelah bergeser pada pola budaya yang bersifat konsumtif, individualis, elitis, serta terkesan menjauh dari realita kehidupan masyarakat sekitar pesantren. Sementara pergeseran paradigma pesantren dipengaruhi oleh beberapa hal. Pertama, pola kepemimpinan pesantren yang masih yang sentralistik dan hierarkis yang terpusat pada satu orang kyai, sehingga hitam-putihnya pesantren sangat ditentukan oleh figur sang kyai. Kedua, kurang improvisasi dalam metodologi, sehingga hanya melahirkan penumpukan keilmuan. Ketiga, terjadinya disorientasi, yaitu pesantren kehilangan kemampuan mendefisinikan dan memosisikan

\footnotetext{
${ }^{23}$ M. Dian Nafi' dkk,. Praksis Pembelajaran, h. 28

${ }^{24}$ Ibid., h. 29.
} 
Pergeseran Paradigma Pesantren, Oleh: Zaenal Arifin

dirinya di tengah realitas sosial yang sedang mengalami perubahan yang sangat cepat.

Implikasi logis pergeseran paradigma pesantren dalah bterjadinya pergeseran budaya dan orientasi pesantren yang berorientasi serbahukum atau fiqih Islam dalam logika al-Ahkam al-Khamsah (lima prinsip hukum) yaitu, wajib, sunnah, haram, makruh dan mubah. Hal ini melahirkan kaca mata hitam-putih dan klaim penyesatan pada sesuatu yang berada di luar syariat. Selain itu, dampak lain yang akan ditimbulkannya adalah pesantren berada di menara gading, elitis, jauh dari realitas sosial. Problem sosialisasi dan aktualisasi ini ditambah lagi dengan problem keilmuan, yaitu terjadi kesenjangan, alienasi dan diferensiasi antara keilmuan pesantren dengan realitas sosial. Elitisme dunia pesantren semakin menjauhkan pesantren dari basis primordialnya, yaitu warga masyarakat. Rasa memiliki masyarakat terhadap pesantren semakin rendah. Sebaliknya, pesantren pun tidak lagi merasa menjadi bagian milik masyarakat. 
Pergeseran Paradigma Pesantren, Oleh: Zaenal Arifin

\section{Daftar Pustaka}

A'la, Abul, Pembaruan Pesantren, Yogyakarta: LKiS, 2006.

Badan Pembina Kesejahteraan Pondok Pesantren Lirboyo. Tiga Tokoh Lirboyo, Kediri: BPK-P2L, 2002.

Baharuddin dan Makin, Moh. Pendidikan Humanistik, Yogyakarta: ArRuzz Media, 2007.

Departemen Pendidikan dan Kebudayaan. Kamus Besar Bahasa Indonesia. Jakarta: Balai Pustaka, 1996.

Farhan, Hamdan dan Syarifuddin, Titik Tengkar Pesantren; Resolusi Konflik Masyarakat Pesantren, Yogyakarta: Pilar Media, 2005.

Fathoni, Abdul Halim. Wajah Baru Pesantren Antara Formalis dan Indeginousitas, (www.Pesantren., 28 August 2007) Tanggal akses 21 Juni 2008.

Haedari, Amin, Panorama Pesantren dalam Cakrawala Modern, Jakarta: Diva Pustaka, 2004.

MHM P2L, HSPK Hasil Sidang Panitia Kecil. Kediri: MHM P2L (Madrasah Hidayatul Mubtadi-ien Pondok Pesantren Lirboyo, 2007.

Leonard Lewisohn, et. al. Warisan Sufi Persia Abad Pertengahan (1150-1500), Terjemahan oleh Ade Alimah, dkk, Jakarta: Pustaka Sufi, 2003.

Mas'ud, Abdurrahman. Intelektual Pesantren: Perhelatan Agama dan Tradisi, Yogyakarta: LKiS, 2004.

Maleong, Lexy J. Metodologi Penelitian Kualitatif, Bandung: Remaja Rosdakarya, 2000.

Muslih, Muhammad, Filsafat Ilmu; Kajian Atas Asumsi Dasar Paradigma dan Kerangka Teori Ilmu Pengetahuan, Yogyakarta: Belukar, 2006.

Nafi', Dian, M., Praksis Pembelajaran Pesantren, Yogyakarta: LKiS, 2007.

Nasir, Haedar. Gerakan Islam Syari'at, Jakarta: PSAP, 2007.

Qomar, Mujamil, Epistemologi Pendidikan Islam, Jakarta: Erlangga, t.th.

Vol. 22 Nomor. 1 Januari 2011 
Pergeseran Paradigma Pesantren, Oleh: Zaenal Arifin

Priatna, Tedi, Ed., Cakrawala Pemikiran Pendidikan Islam, Bandung: Mimbar Pustaka, 2004.

Rahardjo, Mudjia, Ed. Quo Vadis Pendidikan Islam: Membaca Realitas Pendidikan Islam, Sosial dan Keagamaan, Malang: UIN-Malang Press, 2006.

Saifuddin, Ahmad Fedyani, Antropologi Kontemporer: Suatu Pengantar Kritis Mengenai Paradigma. Jakarta: Kencana, 2006.

Salim, Agus, Teori dan Paradigma Penelitian Sosial, Yogyakarta: Tiara Wacana, 2006.

Suhartono, Suparlan, Filsafat Pendidikan Islam, Yogyakarta: Ar-Ruzz, 2006.

Susetyo, Benny. Politik Pendidikan Penguasa, Yogyakarta: LKiS, 2005.

Tim Pena, Kamus Lengkap Bahasa Indonesia, Jakarta: Gramedia Press, t.th.

Wahid, Abdul Rahman, Gus Dur Menjawab Kegelisahan Rakyat, Jakarta: Kompas, 2007.

Wahid, Hasym, dkk., Pesantren Global: Konsep Dasar dan Pedoman Pelaksanaan. Hasil Seminar dan Loka Karya Nasional KMNU, PP Mamba'ul Ulum, Nganjuk, 4-7 Mei 2006.

Wahid, Marzuki, dkk, Pesantren Masa Depan; Wacana Pemberdayaan dan Transformasi Pesantren. Bandung: Pustaka Hidayah, 1999. 